medRxiv preprint doi: https://doi.org/10.1101/2021.08.05.21261674; this version posted August 8, 2021. The copyright holder for this preprint (which was not certified by peer review) is the author/funder, who has granted medRxiv a license to display the preprint in perpetuity.

It is made available under a CC-BY-NC-ND 4.0 International license .

\title{
Development of an online Langerian mindfulness program for stroke survivors and caregivers
}

Authors:

Marika Demers ${ }^{1}$, Francesco Pagnini ${ }^{2,3}$, Deborah Phillips ${ }^{3}$, Brianna Chang ${ }^{1}$, Carolee Winstein ${ }^{1,4}$, Ellen Langer ${ }^{3}$

Affiliations:

1. Division of Biokinesiology and Physical Therapy, University of Southern California, USA

2. Department of Psychology, Università Cattolica del Sacro Cuore, Italy

3. Department of Psychology, Harvard University

4. Department of Neurology, Keck School of Medicine, University of Southern California

Corresponding author:

Marika Demers, OT, PhD

University of Southern California

Motor Behavior and Neurorehabilitation Lab

Division of Biokinesiology and Physical Therapy

1540 Alcazar St., CHP 155

Los Angeles, CA, 90089

Email: demers@pt.usc.edu

Phone: 323- 442-1196

ORCID:

Demers: 0000-0003-4075-1418

Pagnini: 0000-0003-1612-4211

Phillips: 0000-0003-3496-2120

Chang: 0000-0002-5763-7913

Winstein: 0000-0001-9789-4626

Acknowledgements: We thank Sarah Powner for her assistance with the portions of data analysis. We acknowledge the contributions of Didi Matthews, Julie Hershberg, Allison Shapiro and David Karchem for the development of the mindfulness intervention. The project was supported by the Southern California Clinical and Translational Science Institute Voucher Program. MD is supported by the Fonds de la Recherche du Québec Santé.

Declaration of Conflicting Interests: None declared.

Research ethics and patient consent: This study was approved by the IRB from the Health Sciences Campus of the University of Southern California (UP-20-00568) Recruitment was from an existing IRB-approved database, Registry for Aging and Rehabilitation Evaluation-RARE (HS-11-00413). The procedures followed were in accordance with the ethical standards of the University of Southern California and consistent with the revised Helsinki Declaration.

All participants provided informed consent prior to participation.

Trial: NCT04553679 


\title{
Development of an online Langerian mindfulness program for stroke survivors and caregivers
}

\begin{abstract}
Background: Mindfulness is promising for individuals with neurological disorders and caregivers to improve psychological well-being. The potential application of a Langerian mindfulness intervention, focused on the attention to symptom variability, however, is still unknown.
\end{abstract}

Objective: To determine the usability and satisfaction towards an online mindfulness intervention for stroke survivors and caregivers, and the potential effectiveness on psychological well-being.

Methodology: Using a mixed-methods design, 11 stroke survivors and 3 caregivers participated in a three-week, online, Langerian mindfulness intervention promoting attention to variability. A semi-structured interview assessed the intervention's usability and gathered feedback. Selfreported measures about psychological well-being were documented remotely three times (pre, post, one-month).

Results: Participants were highly satisfied with the intervention. None of the outcome measures changed over time, yet participants reported subjective benefits.

Conclusion: Valuable insights were gained from a small sample of stroke survivors and caregivers for the development of a user-friendly and relevant online mindfulness intervention.

Keywords: Stroke, mindfulness, wellbeing 
medRxiv preprint doi: https://doi.org/10.1101/2021.08.05.21261674; this version posted August 8, 2021. The copyright holder for this preprint (which was not certified by peer review) is the author/funder, who has granted medRxiv a license to display the preprint in perpetuity.

It is made available under a CC-BY-NC-ND 4.0 International license .

\section{Introduction}

Stroke is a heterogeneous condition with possible sensorimotor, cognitive, perceptual, social, and psychological sequelae, impacting community participation (Mayo et al., 2002). Stroke survivors have poor perceived physical health (Patel et al., 2006), high incidence of anxiety and depression, (Ayerbe et al., 2013; Campbell Burton et al., 2013) and high levels of dissatisfaction in life, which significantly impact activity and participation (Hartman-Maeir et al., 2007).

The psychosocial impact of stroke extends to spouses, family, and friends who serve in a caregiver role (Low et al., 1999; Rigby et al., 2009). Caregivers are crucial in preserving rehabilitation gains and independence levels, maintaining community participation, and conserving the long-term well-being of stroke survivors (Rigby et al., 2009; Visser-Meily et al., 2006). However, caregiver burden is estimated to be $25-54 \%$ (Rigby et al., 2009). Compared to age-matched peers, caregivers have diminished general health and vitality, and higher prevalence of depression (Anderson et al., 1995; Morimoto et al., 2003).

Currently, some of the most promising clinical treatments for distress reduction and psychological well-being improvement are based on the concept of mindfulness (Pagnini \& Philips, 2015). Mindfulness is multifaceted, but here, it is defined using Ellen Langer's nonmeditative approach as the process of actively making new distinctions about a situation and its environment, or its current context, rather than relying on previous categorizations. Previous studies indicate that many presumed physical or psychological limits result from mindlessness, and participants may benefit from increasing mindfulness (Langer, 2012). While investigation 
medRxiv preprint doi: https://doi.org/10.1101/2021.08.05.21261674; this version posted August 8, 2021. The copyright holder for this preprint (which was not certified by peer review) is the author/funder, who has granted medRxiv a license to display the preprint in perpetuity.

It is made available under a CC-BY-NC-ND 4.0 International license .

into clinical applications of mindfulness has been initiated, there is still significant clinical potential to explore the mindfulness construct as it relates to chronic disease.

Mindfulness interventions based on Langer's mindfulness theory were shown to increase mindfulness in the general population and other cohorts (Alexander et al., 1989; Grant et al., 2004; Langer, 1993, 2000, 2009). One example is an online mindfulness intervention for individuals with amyotrophic lateral sclerosis (ALS) and caregivers. The mindfulness group reported higher quality of life and lower levels of negative emotions, anxiety, and depressive symptoms compared to a waitlist control. Similarly, the caregivers reported lower levels of care burden, depression, and anxiety, and improved well-being and social functioning (Pagnini et al., 2021). Most differences remained stable over time, indicating a sustained effect of the mindfulness intervention, at least short-term. In stroke survivors, two systematic reviews reported a positive trend for mindfulness-based interventions on psychological, physiological, and psychosocial outcomes. However, stronger evidence remains to be established with robust clinical trials (Abbott et al., 2014; Lawrence et al., 2013). Given the favorable results for individuals with neurological conditions and their caregivers, a stroke-specific online mindfulness intervention is promising to increase mindfulness, decrease anxiety and depression, and change patients' beliefs about their disability. Most mindfulness-based interventions use meditation and contemplative practices to promote mindfulness (Pagnini \& Philips, 2015). These require relatively significant time and effort, limiting potential real-life application, particularly in clinical contexts and with caregivers (Jani et al., 2018). The Langerian approach provides easily accessible cognitive exercises inducing openness, cognitive flexibility, creativity, and noticing novelty (Pagnini et al., 2016). 
medRxiv preprint doi: https://doi.org/10.1101/2021.08.05.21261674; this version posted August 8, 2021. The copyright holder for this preprint (which was not certified by peer review) is the author/funder, who has granted medRxiv a license to display the preprint in perpetuity.

It is made available under a CC-BY-NC-ND 4.0 International license .

This study aims to evaluate the usability and satisfaction of a three-week online mindfulness intervention for stroke survivors and caregivers. The secondary exploratory aim is to estimate the potential short-term impact on quality of life and psychological well-being. We hypothesized that the mindfulness intervention will be well accepted and relevant. It is anticipated that minor modifications will be suggested to improve understandability and relevance.

\section{Methods}

\section{Study design}

This feasibility study used a mixed-methods parallel design (Creswell \& Plano-Clark, 2011). A qualitative semi-structured interview performed post-intervention allowed a deeper understanding of users' perceptions of the mindfulness intervention. Quantitative self-reported measures were used at three time points to capture changes in psychological well-being.

\section{Participants}

Stroke survivors and their caregivers were recruited from September 2020 to July 2021.

Recruitment was from an existing IRB-approved database and advertisements through community support groups. Participants were included if they had Internet access on computer, tablet and/or smartphone. Individuals with severe language impairments or those who participated in regular meditation or in a mindfulness program in the past three months were excluded. Participants were purposefully selected to be representative of stroke survivors and caregivers. A sample size of ten stroke survivors was targeted to allow sufficient richness of the qualitative data but was not powered for the secondary aim. This study was approved by the 
medRxiv preprint doi: https://doi.org/10.1101/2021.08.05.21261674; this version posted August 8, 2021. The copyright holder for this preprint (which was not certified by peer review) is the author/funder, who has granted medRxiv a license to display the preprint in perpetuity.

It is made available under a CC-BY-NC-ND 4.0 International license .

University of Southern California (USC) Health Sciences Campus IRB. All participants were informed of the risks and benefits, that their participation was voluntary, that their identity would not be disclosed, and provided electronic informed consent collected through Research Electronic Data Capture (REDCap, Vanderbilt University, Nashville, TN).

\section{Intervention}

The three-week intervention consisted of daily mindfulness exercises and education, with distinct modules for stroke survivors and caregivers. The intervention was accessible via a computer or a smartphone and was hosted on the USC Biokinesiology and Physical Therapy continuing education platform Desire2learn (D2L, Kitchner, Canada). The content was adapted from an intervention for individuals with ALS and caregivers (Pagnini et al., 2021) by experienced clinicians, stroke rehabilitation researchers, stroke survivors, and mindfulness experts. Strokespecific exercises were incorporated to ensure relevance for stroke survivors and caregivers. The general structure of the intervention mixed different mindfulness elements (see Table 1 for the topics covered). All exercises for the stroke survivor included audio recordings.

Insert_Table_1_near_here

\section{Procedures}

Participation was done remotely using the HIPAA compliant platforms Zoom (Zoom Video Communications, Inc., San Jose, CA) for meetings, and REDCap for informed signed consent and assessment. Initially, participants met with the first author (MD) to review the study procedures, obtain written consent, collect socio-demographic information, and complete the 
medRxiv preprint doi: https://doi.org/10.1101/2021.08.05.21261674; this version posted August 8, 2021. The copyright holder for this preprint (which was not certified by peer review) is the author/funder, who has granted medRxiv a license to display the preprint in perpetuity.

It is made available under a CC-BY-NC-ND 4.0 International license .

assessments (see Figure S1 for study timeline). MD oriented participants on how to navigate the online platform. Each participant received a unique identification number and password to access D2L. After a demonstration, participants connected to the platform and accessed the first day's content. MD recorded technical issues, difficulty experienced, assistance provided, and spontaneous feedback reported by participants.

Participants were instructed to accomplish daily exercises at least five days per week. Follow-up emails were sent 48 hours after the beginning of the intervention and every week after.

Participants could contact the research team to ask questions or report difficulties. After completing the intervention, participants completed assessments and a semi-structured interview lasting up to 30 minutes over Zoom. The interview was video recorded and consisted of openended questions about the following topics: feelings, beliefs, reactions to the mindfulness intervention, accessibility of the D2L platform, technical issues, adherence, clarity and relevance of the content, perceived benefits, suggestions to improve user experience, and relevance of the intervention (see Supplementary Material for the interview guide). One-month post-intervention, participants completed assessments using a link sent via email or Zoom.

\section{Exploratory outcome measures}

For stroke survivors, the exploratory self-reported measures were: 1) Stroke Impact Scale (SIS)

(Duncan et al., 2003), 2) Hospital Anxiety and Depression Scale (HADS) (Zigmond \& Snaith, 1983), 3) NIH Toolbox Perceived Stress Survey (PSS) (Kupst et al., 2015), and 4) Single-Item Sleep Quality Scale (SQS) (Snyder et al., 2018). For caregivers, the self-reported measures were:

1) World Health Organization Quality of Life-BREF (WHOQOL-BREF) (World Health 
medRxiv preprint doi: https://doi.org/10.1101/2021.08.05.21261674; this version posted August 8, 2021. The copyright holder for this preprint (which was not certified by peer review) is the author/funder, who has granted medRxiv a license to display the preprint in perpetuity.

It is made available under a CC-BY-NC-ND 4.0 International license .

Organization, 2004), 2) HADS, 3) Zarit Burden Interview (Zarit et al., 1980), 4) PSS, and 5)

SQS. Participants were instructed to consider the impact of the global pandemic when answering the questions.

The SIS 3.0 includes 59 items organized in 8 domains about the impact of stroke on health and life. Each question is scored from 1 (severe difficulty) to 5 (no difficulty) and each domain score is normalized. Higher scores indicate lower perceived impact of stroke. Participants also rated their perceived recovery on a sliding scale from 1 (no recovery) to 100 (full recovery). The HADS is a 14-item scale with 7 items each for anxiety and depression subscales. Each item is scored from 0 to 3, with higher scores indicating higher anxiety or depressive symptoms. The PSS includes 10 items about the occurrence of life stressors scored from 0 (never) to 4 (very often). Higher scores indicate higher perceived stress. The SQS includes an 11-point visual analogue scale about sleep quality in the past week (0: poor, 10: excellent sleep quality). The WHOQOL-BREF comprises 26 questions from 4 domains about health and well-being. The scores are normalized, and higher scores indicate better perceived health and well-being. The Zarit Burden Interview includes 22 questions about caregiver burden rated from 0 (never) to 4 (nearly always). Higher scores indicate higher perceived burden. All measures are valid and reliable for stroke survivors or the general population.

An adapted version of the Post-Study System Usability Questionnaire (PSSUQ) was administered post-intervention to assess D2L platform usability to host the mindfulness intervention (Lewis, 1992). The adapted PSSUQ consists of 5 questions on perceived satisfaction 
medRxiv preprint doi: https://doi.org/10.1101/2021.08.05.21261674; this version posted August 8, 2021. The copyright holder for this preprint (which was not certified by peer review) is the author/funder, who has granted medRxiv a license to display the preprint in perpetuity.

It is made available under a CC-BY-NC-ND 4.0 International license .

with the website. Each question is scored on a 7-point Likert scale from 1 (Strongly Agree) to 7 (Strongly Disagree). Higher scores indicate lower usability.

\section{Data analysis}

The semi-structured interviews were transcribed verbatim. Two research team members independently analyzed the transcripts using the Braun \& Clarke six-step framework for inductive thematic analysis (Braun \& Clarke, 2006). Descriptive statistics were used for the caregivers' data. Since the quantitative data were non normally distributed, non-parametric Friedman tests were used. All statistical procedures were done with JASP version 0.14.1.

\section{Research team and reflexivity}

MD is a female postdoctoral research fellow with $>10$ years of qualitative and clinical experience with stroke survivors. Her experience allowed her to understand the realities of stroke survivors and caregivers, but it might also have impacted negative responses from participants not wanting to disappoint the interviewer. $\mathrm{BC}$ is a female research assistant and at the time was a master's student in stem cell and regenerative medicine at the USC Keck School of Medicine. She received training about qualitative methods from the research team. Personal assumptions and reflections made during data collection and analysis were noted in a reflective journal and discussed with the larger research team.

\section{Results}

Twelve participants (ten stroke survivors and two caregivers) completed the intervention and follow-up assessment, and one stroke survivor was lost at follow-up (socio-demographics 
medRxiv preprint doi: https://doi.org/10.1101/2021.08.05.21261674; this version posted August 8, 2021. The copyright holder for this preprint (which was not certified by peer review) is the author/funder, who has granted medRxiv a license to display the preprint in perpetuity.

It is made available under a CC-BY-NC-ND 4.0 International license.

summarized in Table 2). One additional participant was enrolled in the study but never started the intervention due to an unexpected change in medical status. Another participant dropped from the study after one week due to medical reasons. One additional caregiver supported her parents to complete the intervention. She participated in the interview but did not complete the assessments. Only three participants were familiar with mindfulness, including previous participation in guided meditation or mindfulness.

Insert_Table_2_near_here

\section{Qualitative results}

Four main themes emerged from the qualitative data analysis: 1) Satisfaction with and adherence to the mindfulness intervention, 2) Poor user experience with the web-based platform, 3) Varied perceived benefits from the intervention, and 4) Importance of tailoring the mindfulness intervention (see Supplementary material for individual codes in a word cloud and additional quotes). The themes reflected the participants' perspectives towards the intervention, the difficulties experienced, and potential changes to implement.

Theme 1 - Satisfaction with and adherence to the mindfulness intervention

The first theme describes the knowledge and insights gained from participating in the mindfulness intervention. Eight participants expressed high satisfaction and qualified the intervention as 'good', 'very good', 'enlightening,' or 'interesting'. The intervention aligned well with or exceeded participants' expectations. They appreciated that mindfulness practice was accessible, easy to implement in everyday activities, and encouraged reflection. Participants 
medRxiv preprint doi: https://doi.org/10.1101/2021.08.05.21261674; this version posted August 8, 2021. The copyright holder for this preprint (which was not certified by peer review) is the author/funder, who has granted medRxiv a license to display the preprint in perpetuity.

It is made available under a CC-BY-NC-ND 4.0 International license .

liked that the exercises were simple and easy to understand and apply to their everyday lives. One participant found some exercises were emotionally challenging. Three additional participants had more nuanced opinions of the intervention and expressed being somewhat satisfied with the program. All reported that the exercises offered were not new to them, despite not being familiar with mindfulness. One found some exercises bothersome, as they did not consider her stage in stroke recovery and her capacity. She also reported that some of the language was negative. Another participant felt the intervention lacked direct feedback from a therapist. One felt it was more relevant early post-stroke.

S04: "I enjoyed [the mindfulness intervention]. I got to see a little bit more targeted mindful practice, geared towards me and post-stroke recovery. So, yes, I did enjoy that."

S09: "A lot of [the intervention] seemed like stuff I was already doing or there were examples they were giving me that I couldn't do, so I don't know. [...] I didn't feel like I had a big impact on [me]."

C01: "I didn't have any expectations, but I was pleasantly surprised."

Participants adhered well to the intervention timeline and occasionally skipped days because they were busy, or were fatigued. Some participants maintained a consistent schedule to facilitate adherence. Some participants completed two days at once to compensate for missed days. 
medRxiv preprint doi: https://doi.org/10.1101/2021.08.05.21261674; this version posted August 8, 2021. The copyright holder for this preprint (which was not certified by peer review) is the author/funder, who has granted medRxiv a license to display the preprint in perpetuity.

It is made available under a CC-BY-NC-ND 4.0 International license .

S03: "I got to confess to you, I would miss days and then I would go back, I would do a couple of days at a time."

The number of exercises was considered appropriate and took 15-30 minutes to complete. Opinions about the ideal length of the intervention varied: some participants preferred a twoweek intervention, others found the length appropriate, and one wished it lasted longer.

S03: "It was right at the limit I would say it. I mean, I mean (.) if you would have gone on for another week, it would've been more than I wanted. It was pretty perfect."

S11: "I think the program should be longer. Three weeks, I don't think it's enough to get into mindfulness. But the length of each exercise I thought was good. Ten minutes is a good length of time."

Theme 2 - Poor user experience with the web-based platform

The second theme addresses the usability and accessibility of the D2L platform, accessed on a smartphone, tablet, or computer. The D2L platform was not perceived as user-friendly (see Table 3 for suggestions for improvements). Important issues with accessibility were identified.

Features, such as tests and grades, were distracting. The content was not directly accessible after signing in. The browser did not systematically load the page where the participant left off, requiring them to go through the table of contents each time they logged in. Moreover, the time to download videos was long, and consequently most participants skipped the videos. Two participants mentioned that the pictures were unnecessary and distracting. Participants liked the 
medRxiv preprint doi: https://doi.org/10.1101/2021.08.05.21261674; this version posted August 8, 2021. The copyright holder for this preprint (which was not certified by peer review) is the author/funder, who has granted medRxiv a license to display the preprint in perpetuity. It is made available under a CC-BY-NC-ND 4.0 International license .

checkmark feature that indicated which exercises were completed. Four participants experienced technical issues with their Internet connectivity or their device, which limited their ability to follow the intervention.

S03: "Accessing [the website] was [difficult] because I had a username and a password. I struggled with that a little bit. You can be one character off and it's a problem. I'm not all that technically acclimated. I'm average I would say."

S01: "The nice thing is that when you go to the content page, it shows you the check marks of what of the days you've completed and a couple of 'em I did not remember doing."

Six participants used only the written text and four preferred the written text with the audio recordings. The audio recordings were noted as useful, even if unused. One caregiver wished audio recordings were available for the caregiver module.

C03: "I wish the caregiver portion had an audio component [...] My mom would have felt more competent if she could just listen to it while cleaning or whatnot."

S11: "1 like having the words to read and having the recording."

Insert_Table_3_near_here 
medRxiv preprint doi: https://doi.org/10.1101/2021.08.05.21261674; this version posted August 8, 2021. The copyright holder for this preprint (which was not certified by peer review) is the author/funder, who has granted medRxiv a license to display the preprint in perpetuity.

It is made available under a CC-BY-NC-ND 4.0 International license .

Theme 3 - Varied perceived benefits from the intervention

The third theme encompasses the perceived gains related to the mindfulness exercises and education. The most common ideas were that the intervention increased participants' general knowledge about mindfulness and helped change their mindsets, attitudes, and viewpoints. Many participants gave examples of how they applied mindfulness in their daily lives. Participants highlighted that the intervention stimulated discussion with their loved ones and gave them tools to navigate challenging or stressful situations. Two participants with poor sleep quality reported that the program offered strategies to go back to sleep.

S03: "It was, overall, very beneficial to me. Mindfulness was kind of like shifting your viewpoint just a little bit and that little bit was helpful."

C01: "It's sort of like a meditation, but active meditation. It helps you get your mind from a negative thought to a positive thought."

Theme 4- Importance of tailoring the mindfulness intervention

The fourth theme describes the strong perception that a mindfulness intervention should be personalized and adapted to individual situations, including a global pandemic. Both stroke survivors and caregivers discussed how stroke changed their lives. Stroke survivors mentioned how their routine, meaningful activities, roles, and social participation were disrupted by the stroke. Most exercises were considered relevant. However, participants felt that some exercises were not targeted to their capacity, stage of recovery, or living situation. For example, one exercise encourages stroke survivors to use their paretic hand to perform activities. For those 
with severe impairments, holding an object was impossible, and consequently such exercises created frustrations. One stroke survivor mentioned that some exercises required to express emotions, which was in conflict with her own culture. Perception of stroke recovery differed greatly between participants. Many were dissatisfied with their recovery, often due to slower recovery or persisting impairments. Their outlook on life changed at different time points poststroke, which stressed the importance of tailoring exercises.

S03: "If you ask me to move my left hand, I can't do that or walk or something [.] It said walk someplace or do something like that. I can't walk."

S01: "Well obviously, I wish I had recovered more especially on my left side and there have been some other impacts of my stroke over the years, other than the immediate ones. I've definitely had some physical issues that have come up in recent years that are sort of manifestations of the stroke or the impact on my brain that are more noticeable now."

S11: "If you've had a stroke, after a certain time, you, you've adjusted your life to a certain way."

The COVID-19 pandemic greatly impacted all participants and heightened uncertainties. Most participants expressed how the pandemic impacted their answers. The pandemic allowed most participants to have the time to take part in this program, as many usual activities were disrupted. One participant had many groups/interventions on the computer, which limited his willingness to 
medRxiv preprint doi: https://doi.org/10.1101/2021.08.05.21261674; this version posted August 8, 2021. The copyright holder for this preprint (which was not certified by peer review) is the author/funder, who has granted medRxiv a license to display the preprint in perpetuity.

It is made available under a CC-BY-NC-ND 4.0 International license .

do another online intervention. Three participants mentioned that some exercises were not aligned with the global events.

S04: "It is hard to say that COVID didn't influence anything. Every single aspect of life is affected by [COVID-19]."

C01: "COVID has us doing not as much, so that [intervention] was helpful."

\section{Quantitative results}

The self-reported measures took between 10-90 minutes to administer remotely. Two caregiverstroke dyads required assistance from a researcher to complete the assessments. Among stroke survivors, there were no significant changes in scores for the SIS, HADS, PSS, with high variability between participants (Table 4). The HADS showed a trend towards reduced anxiety and depression, with five participants showing lower levels of anxiety and depression postintervention (Figure 1). Four participants improved in their sleep quality from pre to post intervention, but this was not maintained at the one-month follow-up. During the qualitative interview, participants mentioned extenuating factors, such as pain or stress from the US elections, to explain sleep quality deterioration. The caregiver sample was not large enough to assess changes from the intervention, and no clear changes were noted.

Insert_Figure_1_and_Table_4_near_here 
medRxiv preprint doi: https://doi.org/10.1101/2021.08.05.21261674; this version posted August 8, 2021. The copyright holder for this preprint (which was not certified by peer review) is the author/funder, who has granted medRxiv a license to display the preprint in perpetuity.

It is made available under a CC-BY-NC-ND 4.0 International license .

The average usability measured with the PSSUQ was $13.7 \pm 10.0$ (range from 5-33), which indicates limited usability. Five participants with limited computer savviness experienced difficulty accessing the website content during the pre-intervention trial. The most common difficulties were signing in with the username and password $(n=3)$ and navigating the platform $(n=5)$. Minimal verbal guidance resolved difficulties. No difficulties were experienced by those with greater familiarity with technology. One dyad continued to have trouble accessing the content and required support from the research team.

\section{Discussion}

This feasibility study aimed to evaluate the usability, satisfaction, and potential effectiveness of an online mindfulness intervention for stroke survivors and caregivers. The experience from the mindfulness intervention was positive overall, with high levels of satisfaction and good adherence to the daily exercises. The qualitative and quantitative data highlighted usability challenges with the online platform used. Participants perceived subjective benefits from the intervention, yet no significant changes were observed on self-reported measures. Positive trends from pre to post were noted on the HADS and the SQS. Insights from stroke survivors and participants offered simple strategies to better tailor the intervention, improve the relevance of the exercise, and facilitate accessibility.

Perspectives from a heterogeneous sample of stroke survivors and caregivers were valuable to push beyond usability testing. In recent years, more studies explored the benefits of mindfulnessbased stress reduction or mindfulness-based cognitive therapy for stroke survivors (Abbott et al., 2014; Lawrence et al., 2013). However, to our knowledge, only two studies captured the 
medRxiv preprint doi: https://doi.org/10.1101/2021.08.05.21261674; this version posted August 8, 2021. The copyright holder for this preprint (which was not certified by peer review) is the author/funder, who has granted medRxiv a license to display the preprint in perpetuity.

It is made available under a CC-BY-NC-ND 4.0 International license .

experience of stroke survivors with mindfulness (Jani et al., 2018; Wang et al., 2019). Jani et al. (2018) found that a 2-hour in-person mindfulness-based stress reduction showed positive acceptability, but participants had trouble maintaining focus and concentration throughout the session. Similarly, Wang et al. (2019) showed that a mindfulness and relaxation program is acceptable, user-friendly, and beneficial for stroke survivors. This is the first study that used Langerian mindfulness with stroke survivors. The integration of mindfulness practice in everyday life seemed particularly appreciated and could be relevant for the clinical applicability and scalability of the intervention. Compared to meditation, Langerian mindfulness with attention to symptoms variability requires significantly less time and is easily implementable at a time convenient for the participant, which can vary from day to day.

Positive benefits were reported in the semi-structured interview, but this was not observed in the self-reported measures of psychological well-being. The small sample size and large interindividual baseline variability may explain why changes were not detected. Moreover, the evaluation timeline may be too short to observe changes in quality of life and psychological well-being. Participants reported implementing mindfulness strategies in their daily lives, such as changes in mindset during negative events or better ability to remain calm to solve problems in challenging situations. This suggests that the skills acquired during a short three-week online intervention can be transferred to some extent to everyday life. Despite the lack of quantitative changes, the subjective reports seem in line with the results obtained with a similar intervention on people with ALS (Pagnini et al., 2021). 
medRxiv preprint doi: https://doi.org/10.1101/2021.08.05.21261674; this version posted August 8, 2021. The copyright holder for this preprint (which was not certified by peer review) is the author/funder, who has granted medRxiv a license to display the preprint in perpetuity.

It is made available under a CC-BY-NC-ND 4.0 International license .

Many participants experienced difficulties with accessibility and usability of the D2L platform, especially those with limited familiarity with technology. The D2L platform was not perceived as user-friendly, despite its wide use in higher education. The results contrast previous studies that found D2L to be user-friendly and intuitive to use in a tailored academic environment (Aldraheti, 2020; Chawdhry et al., 2011). The primary difference concerns our cohort (older adults, lower levels of education, less exposure to technology and more clinical issues). The results suggest that the initial training and visual guide provided were not sufficient for participants with limited familiarity with computers. Modifications may involve the use of shortcuts to direct participants to the content, simplifying the navigation menu, and providing additional guidance and training.

This study is not without limitations. Our sample was small and heterogenous. This study was not powered to detect changes in the self-reported measures, but it provided guidance on the selection of outcome measures for a larger intervention study. The possibility of a social desirability bias is not excluded since participants may have wanted to please the researchers. The results may have limited generalizability due to the small sample size and strong proportion of males and people with right hemisphere stroke. The entire study was conducted during COVID-19, which may have significantly disrupted daily life and afforded time to participate in this kind of intervention.

\section{Conclusions}

This study supports the feasibility of a three-week online mindfulness intervention for stroke survivors and caregivers. Feedback and suggestions from the participants provided guidance to 
medRxiv preprint doi: https://doi.org/10.1101/2021.08.05.21261674; this version posted August 8, 2021. The copyright holder for this preprint (which was not certified by peer review) is the author/funder, who has granted medRxiv a license to display the preprint in perpetuity.

It is made available under a CC-BY-NC-ND 4.0 International license .

better tailor the intervention and improve the usability of the platform used. Based on the results

obtained, the next step is to make changes to improve the intervention, such as simplify access to the content, modify exercise wording, offer options to record notes, customize the exercises based on current ability or situation, and provide audio recordings for all modules. This study is a precursor step in the design of a large, randomized control trial to determine the effectiveness of an online mindfulness intervention with attention to symptom variability for stroke survivors and caregivers.

\section{References}

Abbott, R. A., Whear, R., Rodgers, L. R., Bethel, A., Thompson Coon, J., Kuyken, W., Stein, K., \& Dickens, C. (2014). Effectiveness of mindfulness-based stress reduction and mindfulness based cognitive therapy in vascular disease: A systematic review and metaanalysis of randomised controlled trials. Journal of Psychosomatic Research, 76(5), 341351. https://doi.org/10.1016/j.jpsychores.2014.02.012

Alexander, C. N., Langer, E. J., Newman, R. I., Chandler, H. M., \& Davies, J. L. (1989). Transcendental Meditation, mindfulness, and longevity: An experimental study with the elderly. Journal of Personality and Social Psychology, 57(6), 950-964. http://dx.doi.org.libproxy1.usc.edu/10.1037/0022-3514.57.6.950

Anderson, C. S., Linto, J., \& Stewart-Wynne, E. G. (1995). A population-based assessment of the impact and burden of caregiving for long-term stroke survivors. Stroke. https://doi.org/10.1161/01.STR.26.5.843 
medRxiv preprint doi: https://doi.org/10.1101/2021.08.05.21261674; this version posted August 8, 2021. The copyright holder for this preprint (which was not certified by peer review) is the author/funder, who has granted medRxiv a license to display the preprint in perpetuity. It is made available under a CC-BY-NC-ND 4.0 International license .

Ayerbe, L., Ayis, S., Wolfe, C. D. A., \& Rudd, A. G. (2013). Natural history, predictors and outcomes of depression after stroke: Systematic review and meta-analysis. The British Journal of Psychiatry, 202(1), 14-21. https://doi.org/10.1192/bjp.bp.111.107664

Braun, V., \& Clarke, V. (2006). Using thematic analysis in psychology. Qualitative Research in Psychology, 3(2), 77-101. https://doi.org/10.1191/1478088706qp063oa

Campbell Burton, C. A., Murray, J., Holmes, J., Astin, F., Greenwood, D., \& Knapp, P. (2013). Frequency of anxiety after stroke: A systematic review and meta-analysis of observational studies. International Journal of Stroke, 8(7), 545-559. https://doi.org/10.1111/j.1747-4949.2012.00906.x

Creswell, J. W., \& Plano-Clark, V. L. (2011). Choosing a mixed methods design. Designing and Conducting Mixed Method Research.

Duncan, P. W., Bode, R. K., Lai, S. M., \& Perera, S. (2003). Rasch analysis of a new strokespecific outcome scale: The stroke impact scale. Archives of Physical Medicine and Rehabilitation, 84(7), 950-963. https://doi.org/10.1016/S0003-9993(03)00035-2

Grant, A. M., Langer, E. J., Falk, E., \& Capodilupo, C. (2004). Mindful creativity: Drawing to draw distinctions. Creativity Research Journal. https://doi.org/10.1207/s15326934crj1602\&3_9

Hartman-Maeir, A., Soroker, N., Ring, H., Avni, N., \& Katz, N. (2007). Activities, participation and satisfaction one-year post stroke. Disability and Rehabilitation, 29(7), 559-566. https://doi.org/10.1080/09638280600924996

Jani, B. D., Simpson, R., Lawrence, M., Simpson, S., \& Mercer, S. W. (2018). Acceptability of mindfulness from the perspective of stroke survivors and caregivers: A qualitative study. Pilot and Feasibility Studies, 4(1), 57. https://doi.org/10.1186/s40814-018-0244-1 
medRxiv preprint doi: https://doi.org/10.1101/2021.08.05.21261674; this version posted August 8, 2021. The copyright holder for this preprint (which was not certified by peer review) is the author/funder, who has granted medRxiv a license to display the preprint in perpetuity. It is made available under a CC-BY-NC-ND 4.0 International license .

Kupst, M. J., Butt, Z., Stoney, C. M., Griffith, J. W., Salsman, J. M., Folkman, S., \& Cella, D. (2015). Assessment of stress and self-efficacy for the NIH Toolbox for Neurological and Behavioral Function. Anxiety, Stress, \& Coping, 28(5), 531-544.

https://doi.org/10.1080/10615806.2014.994204

Langer, E. J. (1993). A Mindful Education. Educational Psychologist. https://doi.org/10.1207/s15326985ep2801_4

Langer, E. J. (2000). Mindful learning. Current Directions in Psychological Science. https://doi.org/10.1111/1467-8721.00099

Langer, E. J. (2009). Counterclockwise: Mindful Health and the Power of Possibility. Ballantine Books.

Langer, E. J. (2012). The mindless use of medical data. Journal of Business Research. https://doi.org/10.1016/j.jbusres.2011.02.018

Lawrence, M., Booth, J., Mercer, S., \& Crawford, E. (2013). A Systematic Review of the Benefits of Mindfulness-Based Interventions following Transient Ischemic Attack and Stroke. International Journal of Stroke, 8(6), 465-474. https://doi.org/10.1111/ijs.12135

Lewis, J. R. (1992). Psychometric Evaluation of the Post-Study System Usability Questionnaire: The PSSUQ. Proceedings of the Human Factors Society Annual Meeting, 36(16), 12591260. https://doi.org/10.1177/154193129203601617

Low, J. T. S., Payne, S., \& Roderick, P. (1999). The impact of stroke on informal carers: A literature review. In Social Science and Medicine. https://doi.org/10.1016/S02779536(99)00194-X

Mayo, N. E., Wood-Dauphinee, S., Cote, R., Durcan, L., Carlton, J., Côté, R., Durcan, L., \& Carlton, J. (2002). Activity, participation, and quality of life 6 months poststroke. 
medRxiv preprint doi: https://doi.org/10.1101/2021.08.05.21261674; this version posted August 8, 2021. The copyright holder for this preprint (which was not certified by peer review) is the author/funder, who has granted medRxiv a license to display the preprint in perpetuity. It is made available under a CC-BY-NC-ND 4.0 International license .

Archives of Physical Medicine and Rehabilitation, 83(8), 1035-1042.

https://doi.org/10.1053/apmr.2002.33984

Morimoto, T., Schreiner, A. S., \& Asano, H. (2003). Caregiver burden and health-related quality of life among Japanese stroke caregivers. Age and Ageing, 32(2), 218-223. https://doi.org/10.1093/ageing/32.2.218

Pagnini, F., Bercovitz, K., \& Langer, E. J. (2016). Perceived Control and Mindfulness: Implications for Clinical Practice. Journal of Psychotherapy Integration, 26(2), 91-102. https://doi.org/10.1093/acprof:oso/9780190257040.003.0006

Pagnini, F., \& Philips, D. (2015). Being mindful about mindfulness. In The Lancet Psychiatry. https://doi.org/10.1016/S2215-0366(15)00041-3

Pagnini, F., Phillips, D., Haulman, A., Bankert, M., Simmons, Z., \& Langer, E. (2021). An online non-meditative mindfulness intervention for people with ALS and their caregivers: A randomized controlled trial. Amyotrophic Lateral Sclerosis and Frontotemporal Degeneration, 1-12. https://doi.org/10.1080/21678421.2021.1928707

Patel, M. D., Tilling, K., Lawrence, E., Rudd, A. G., Wolfe, C. D. A., \& McKevitt, C. (2006). Relationships between long-term stroke disability, handicap and health-related quality of life. Age and Ageing, 35(3), 273-279. https://doi.org/10.1093/ageing/afj074

Rigby, H., Gubitz, G., \& Phillips, S. (2009). A systematic review of caregiver burden following stroke. International Journal of Stroke, 4(4), 285-292. https://doi.org/10.1111/j.17474949.2009.00289.x

Snyder, E., Cai, B., DeMuro, C., Morrison, M. F., \& Ball, W. (2018). A new single-item sleep quality scale: Results of psychometric evaluation in patients with chronic primary 
medRxiv preprint doi: https://doi.org/10.1101/2021.08.05.21261674; this version posted August 8, 2021. The copyright holder for this preprint (which was not certified by peer review) is the author/funder, who has granted medRxiv a license to display the preprint in perpetuity. It is made available under a CC-BY-NC-ND 4.0 International license .

insomnia and depression. Journal of Clinical Sleep Medicine, 14(11), 1849-1857. https://doi.org/10.5664/jcsm.7478

Visser-Meily, A., Post, M., Gorter, J. W., Berlekom, S. B. V., Van Den Bos, T., \& Lindeman, E. (2006). Rehabilitation of stroke patients needs a family-centred approach. Disability and Rehabilitation, 28(24), 1557-1561. https://doi.org/10.1080/09638280600648215

Wang, X., Smith, C., Ashley, L., \& Hyland, M. E. (2019). Tailoring Self-Help Mindfulness and Relaxation Techniques for Stroke Survivors: Examining Preferences, Feasibility and Acceptability. Frontiers in Psychology, 10. https://doi.org/10.3389/fpsyg.2019.00391

World Health Organization. (2004). The World Health Organization Quality of Life (WHOQOL)-BREF. World Health Organization.

Zarit, S. H., Reever, K. E., \& Bach-Peterson, J. (1980). Relatives of the impaired elderly: Correlates of feelings of burden. Gerontologist. https://doi.org/10.1093/geront/20.6.649 Zigmond, A. S., \& Snaith, R. P. (1983). The Hospital Anxiety and Depression Scale. Acta Psychiatrica Scandinavica, 67(6), 361-370. https://doi.org/10.1111/j.16000447.1983.tb09716.x 
medRxiv preprint doi: https://doi.org/10.1101/2021.08.05.21261674; this version posted August 8, 2021. The copyright holder for this preprint (which was not certified by peer review) is the author/funder, who has granted medRxiv a license to display the preprint in perpetuity.

It is made available under a CC-BY-NC-ND 4.0 International license .

Table 1. Structure of the mindfulness program

\begin{tabular}{|c|c|c|}
\hline Topic & Definition & Example \\
\hline $\begin{array}{l}\text { Attention to } \\
\text { variability }\end{array}$ & $\begin{array}{l}\text { The key concept is that the world around us, } \\
\text { and each one of us, is always changing. If you } \\
\text { are able to notice subtle changes in the external } \\
\text { word, as well as in how you feel, you will find } \\
\text { that negative feelings, whether psychological } \\
\text { or physical, are not always present. Thus, you } \\
\text { can change the usual tendency to view things } \\
\text { as if they are unchanging - a mindless } \\
\text { construct of the world. }\end{array}$ & $\begin{array}{l}\text { Try to find } 5 \text { ways in } \\
\text { which the weather is } \\
\text { different today than } \\
\text { yesterday. }\end{array}$ \\
\hline $\begin{array}{l}\text { Positive and negative } \\
\text { events }\end{array}$ & $\begin{array}{l}\text { The same event may be seen as either positive } \\
\text { or negative, depending on one's perspective. If } \\
\text { we change our point of view then our } \\
\text { perception about what we were certain is a } \\
\text { negative event can, from that different } \\
\text { perspective, be viewed as positive. That is, we } \\
\text { can reframe a negative perception of an event } \\
\text { by answering a simple question: "In what ways } \\
\text { might this be good for me? Or "What about } \\
\text { this situation could be seen as good?" With } \\
\text { the disability following a stroke, we can try to } \\
\text { find a different perspective about the illness. } \\
\text { We see that our experience of the illness is a } \\
\text { reflection of the view we take rather than of } \\
\text { the illness itself. We can find many individuals } \\
\text { who are able to reframe their experiences of } \\
\text { their own illnesses by including views that } \\
\text { express the positive experiences or } \\
\text { opportunities the illness has brought to their } \\
\text { lives. This perspective shifting is a very } \\
\text { mindful exercise and a very valuable coping } \\
\text { resource. }\end{array}$ & $\begin{array}{l}\text { You miss a bus to } \\
\text { meet an important } \\
\text { person in your life. } \\
\text { Try to find } 5 \text { reasons } \\
\text { how that could be } \\
\text { positive. }\end{array}$ \\
\hline Unpredictability & $\begin{array}{l}\text { A mindful view of the future acknowledges its } \\
\text { ultimate unpredictability, as is the course of } \\
\text { the participant's disability. Such } \\
\text { unpredictability opens up the possibilities for a } \\
\text { more positive perception of the future than had } \\
\text { been conceived. }\end{array}$ & $\begin{array}{l}\text { Allow yourself to } \\
\text { consider this } \\
\text { question: Can you } \\
\text { predict the course of } \\
\text { your stroke } \\
\text { recovery? If so, } \\
\text { please find } 3 \text { ways in } \\
\text { which your certainty } \\
\text { could be faulty. For } \\
\text { each of those } \\
\text { reasons, describe the } \\
\text { way in which it is }\end{array}$ \\
\hline
\end{tabular}


medRxiv preprint doi: https://doi.org/10.1101/2021.08.05.21261674; this version posted August 8, 2021. The copyright holder for this preprint (which was not certified by peer review) is the author/funder, who has granted medRxiv a license to display the preprint in perpetuity.

It is made available under a CC-BY-NC-ND 4.0 International license .

\begin{tabular}{|c|c|c|}
\hline & & $\begin{array}{l}\text { both positive and } \\
\text { negative. }\end{array}$ \\
\hline Sense Making & $\begin{array}{l}\text { Disability and symptoms tend to be perceived } \\
\text { as something that stays unchanging. However, } \\
\text { it is unlikely that all symptoms are always } \\
\text { present at the same intensity or at the same } \\
\text { level of impairment. Reflecting about } \\
\text { symptoms and your ability to do things that are } \\
\text { important to you allows for understanding their } \\
\text { variability and making sense of this can help } \\
\text { develop an understanding that there are often } \\
\text { many reasons for their variability. Once we } \\
\text { can identify even a few reasons, feelings of } \\
\text { increased control and awareness follow. }\end{array}$ & $\begin{array}{l}\text { Think about your } \\
\text { past, particularly the } \\
\text { most meaningful } \\
\text { moments in your } \\
\text { life. Can you see } \\
\text { how these events } \\
\text { may have led to one } \\
\text { another or somehow } \\
\text { be connected in } \\
\text { some way? }\end{array}$ \\
\hline $\begin{array}{l}\text { Novelty seeking and } \\
\text { novelty producing }\end{array}$ & $\begin{array}{l}\text { The attitude of paying attention to new } \\
\text { elements requires an open and curious } \\
\text { orientation toward the world and towards } \\
\text { oneself. Novelty producing actively creates } \\
\text { new categories of thinking rather than relying } \\
\text { on previously constructed categories and } \\
\text { distinctions about the world (Langer, 1989). } \\
\text { Novelty seeking is also related to the concept } \\
\text { of flexibility or using feedback from the } \\
\text { environment to make any responsive } \\
\text { adaptations to one's thinking and behavior. } \\
\text { These attitudes may be improved in an effort } \\
\text { to be more mindful. }\end{array}$ & $\begin{array}{l}\text { We invite you to } \\
\text { consider this: What } \\
\text { are } 5 \text { ways you } \\
\text { could make } \\
\text { something in your } \\
\text { home more personal } \\
\text { and appealing to } \\
\text { you? }\end{array}$ \\
\hline
\end{tabular}


medRxiv preprint doi: https://doi.org/10.1101/2021.08.05.21261674; this version posted August 8, 2021. The copyright holder for this preprint (which was not certified by peer review) is the author/funder, who has granted medRxiv a license to display the preprint in perpetuity. It is made available under a CC-BY-NC-ND 4.0 International license .

Table 2. Socio-demographics of participants

\begin{tabular}{lcc}
\hline Characteristics & $\begin{array}{c}\text { Stroke survivors } \\
(\mathbf{n = 1 1})\end{array}$ & $\begin{array}{c}\text { Caregivers } \\
(\mathbf{n = 3})\end{array}$ \\
\hline Gender (Female, \%) & 27.3 & 100 \\
Age (Mean \pm SD) & $65.1 \pm 12.1$ & $59.7 \pm 21.5$ \\
Race (\%) & 0 & 0 \\
$\quad$ American Indian or Alaska Native & 27.3 & 66.7 \\
Asian & 0 & 0 \\
Black & 0 & 0 \\
Native Hawaiian or Pacific Islander & 63.6 & 33.3 \\
White or Caucasian & 9.1 & 0 \\
More than one Race & & 0 \\
Ethnicity (\%) & 9.1 & 100 \\
$\quad$ Hispanic & 90.9 & 100 \\
$\quad$ Non-Hispanic & 36.4 & 0 \\
Ambulation (without assistive device, \%) & & 66.7 \\
Living situation (\%) & 27.3 & 33.3 \\
Alone & 36.4 & $\mathrm{n} / \mathrm{a}$ \\
With spouse & 36.4 & $\mathrm{n} / \mathrm{a}$ \\
$\quad$ With family & $4.7 \pm 3.7$ & $\mathrm{n} / \mathrm{a}$ \\
Time since stroke (years, mean \pm SD) & 36.4 & \\
Hemisphere affected by the stroke (Left, \%) & 63.6 & \\
Stroke type (Ischemic stroke, \%) & & \\
\hline
\end{tabular}


medRxiv preprint doi: https://doi.org/10.1101/2021.08.05.21261674; this version posted August 8, 2021. The copyright holder for this preprint (which was not certified by peer review) is the author/funder, who has granted medRxiv a license to display the preprint in perpetuity.

It is made available under a CC-BY-NC-ND 4.0 International license .

Table 3. Suggestions for improvements to the Mindfulness program

\begin{tabular}{|c|c|}
\hline Items to address & Quotes \\
\hline $\begin{array}{l}\text { Tailor exercises based on abilities, } \\
\text { stages of recovery and living } \\
\text { situation }\end{array}$ & $\begin{array}{l}\text { S10: "So sometimes it would say things [.] they would } \\
\text { ask me to do things that I wasn't capable of doing. I, I'm } \\
\text { not for instance going [... I'm not going to the store right } \\
\text { now for instance and, you know, like it might say 'go } \\
\text { look at a flower' or something that wasn't available or } \\
\text { something like that." }\end{array}$ \\
\hline $\begin{array}{l}\text { Ensure that the exercises reflect } \\
\text { the current COVID-19 situation }\end{array}$ & $\begin{array}{l}\text { S04: "In these COVID time, no one is taking showers } \\
\text { everyday (laughs). No, but there are things that are out of } \\
\text { sync to what normally happens or when it happens." }\end{array}$ \\
\hline Simplify access to the content & $\begin{array}{l}\text { S05: "I felt I should be able to log in and be where I left } \\
\text { off the time before and go forward. But every time, I had } \\
\text { to log in, then find the program, then find where I was, } \\
\text { and it wasn't intuitive the way you do it and sometimes it } \\
\text { wouldn't go. You have to go to portal [.] like it wasn't } \\
\text { like you click on one thing." }\end{array}$ \\
\hline Remove the pictures and artwork & $\begin{array}{l}\text { S07: "I think the only part that perhaps is unnecessary } \\
\text { was the artwork." }\end{array}$ \\
\hline $\begin{array}{l}\text { Offer a place for participants to } \\
\text { record their thoughts and ideas } \\
\text { after each exercise }\end{array}$ & $\begin{array}{l}\text { S01: "I think that somebody could if they had a place } \\
\text { where they could type in some notes. [The participant] } \\
\text { could give you a response that would maybe be more } \\
\text { mindful about how that topic area affected them." }\end{array}$ \\
\hline $\begin{array}{l}\text { Change the wording used to be } \\
\text { more inclusive }\end{array}$ & $\begin{array}{l}\text { S11: "Sometimes I had trouble with particular articles } \\
\text { like it said: 'come up with three ideas why this might be } \\
\text { a good thing or a bad thing'. I could only come up with } \\
\text { one idea." Interviewer: "Would you suggest that we just } \\
\text { say: 'Come up with ideas' plural and not specify a } \\
\text { number?" S11: "It would actually be less like you are } \\
\text { failing." }\end{array}$ \\
\hline $\begin{array}{l}\text { Provide an overview of the daily } \\
\text { exercises and specify times at } \\
\text { which each exercise should be } \\
\text { done }\end{array}$ & $\begin{array}{l}\text { S01: "some of the exercises have an introduction to them } \\
\text { and then followed by exercises. 'Time just goes straight } \\
\text { to exercises and hum I think you should be trying to have } \\
\text { them be more consistent always have them go to an } \\
\text { introduction. For example, even if the introduction is just } \\
\text { to say: 'Today, we're just doing exercises' and no intro." } \\
\text { S04: "It would be nice to have maybe like: 'do this in the } \\
\text { morning', 'do this in the evening', 'do this...' so that you } \\
\text { sort of [..] I think there could be a little bit of structure } \\
\text { around when in the time of the day some of these } \\
\text { prompts could come up." }\end{array}$ \\
\hline $\begin{array}{l}\text { Offer audio recordings for the } \\
\text { entire program }\end{array}$ & $\begin{array}{l}\text { S11: "It would be good if [the introduction to each } \\
\text { module] would be recorded also, because some people } \\
\text { have a hard time reading after having had a stroke or a } \\
\text { hard time concentrating." }\end{array}$ \\
\hline
\end{tabular}


medRxiv preprint doi: https://doi.org/10.1101/2021.08.05.21261674; this version posted August 8, 2021. The copyright holder for this preprint (which was not certified by peer review) is the author/funder, who has granted medRxiv a license to display the preprint in perpetuity.

It is made available under a CC-BY-NC-ND 4.0 International license .

Add a concluding statement at the end of the program
S05: "at the end of this, you will A, B, C, D. There was no feel for that. Like at the end of this, you just feel nothing. I mean, even if they said you may not notice any changes or anything, but I felt like I was supposed to know at the end of this something."

Table 4. Quality of life and wellbeing self-reported measures

\begin{tabular}{|c|c|c|c|c|c|}
\hline \multicolumn{6}{|c|}{ Stroke survivors $(N=11)$} \\
\hline & Pre & Post & Follow-up & $\begin{array}{c}\text { Chi- } \\
\text { Squared } \\
(\mathbf{d f}=2)\end{array}$ & P-value \\
\hline Stroke Impact Scale & $268.6 \pm 67.3$ & $266.4 \pm 64.2$ & $286.1 \pm 60.0$ & 3.19 & 0.203 \\
\hline $\begin{array}{l}\text { Stroke Impact Scale } \\
\text { (recovery score) }\end{array}$ & $52.3 \pm 26.9$ & $51.5 \pm 27.3$ & $65.9 \pm 19.2$ & 4.44 & 0.109 \\
\hline Hospital Anxiety and & & & & & \\
\hline Depression Scale & & & & & \\
\hline Depression & $6.1 \pm 3.8$ & $5.5 \pm 3.2$ & $5.0 \pm 3.8$ & 2.54 & 0.281 \\
\hline Anxiety & $5.6 \pm 3.4$ & $5.4 \pm 2.8$ & $4.6 \pm 2.2$ & 5.42 & 0.067 \\
\hline NIH Perceived Stress & $26.0 \pm 6.3$ & $21.3 \pm 10.0$ & $22.0 \pm 6.3$ & 2.13 & 0.345 \\
\hline Single-item sleep Quality & $6.4 \pm 2.5$ & $7.3 \pm 2.0$ & $6.6 \pm 2.6$ & 1.67 & 0.435 \\
\hline \multicolumn{6}{|c|}{ Caregivers $(N=2 *)$} \\
\hline & Pre & Post & Follow-up & & \\
\hline WHOQoL-BREF & $53.5 \pm 13.4$ & $37.5 \pm 9.2$ & $63.0 \pm 0.0$ & & \\
\hline Physical health & & & & & \\
\hline WHOQoL-BREF & $44.0 \pm 8.5$ & $50.5 \pm 17.7$ & $50.0 \pm 8.5$ & & \\
\hline Psychological & & & & & \\
\hline WHOQOL-BREF & $44.0 \pm 0.0$ & $47.0 \pm 4.2$ & $53 \pm 4.2$ & & \\
\hline Social relationships & & & & & \\
\hline WHOQoL-BREF & $53.0 \pm 4.2$ & $53 \pm 4.2$ & $69 \pm 0.0$ & & \\
\hline Environment & & & & & \\
\hline Zarit Burden Inventory & $43.0 \pm 9.9$ & $40.0 \pm 19.8$ & $38.5 \pm 19.1$ & & \\
\hline Hospital Anxiety and & & & & & \\
\hline Depression Scale & & & & & \\
\hline Depression & $9.0 \pm 1.4$ & $7.5 \pm 2.1$ & $7.5 \pm 2.1$ & & \\
\hline Anxiety & $9.5 \pm 0.7$ & $6.0 \pm 1.4$ & $9.0 \pm 2.8$ & & \\
\hline NIH Perceived Stress & $33 \pm 1.4$ & $28.5 \pm 2.1$ & $29.5 \pm 35$ & & \\
\hline Single-item sleep Quality & $3.5 \pm 0.7$ & $7.5 \pm 2.1$ & $7.0 \pm 2.8$ & & \\
\hline
\end{tabular}


medRxiv preprint doi: https://doi.org/10.1101/2021.08.05.21261674; this version posted August 8, 2021. The copyright holder for this preprint (which was not certified by peer review) is the author/funder, who has granted medRxiv a license to display the preprint in perpetuity.

It is made available under a CC-BY-NC-ND 4.0 International license .

Figure 1. Scores on the quality of life and psychological well-being measures

Figure 1 caption: Individual and mean scores at 3 time points: pre-, post-intervention, and 1month follow-up. Thicker lines are mean scores. Thin pale lines are individual scores for stroke survivors $(n=11)$ and dotted lines are individual scores for caregivers $(n=2)$. 


\section{B}

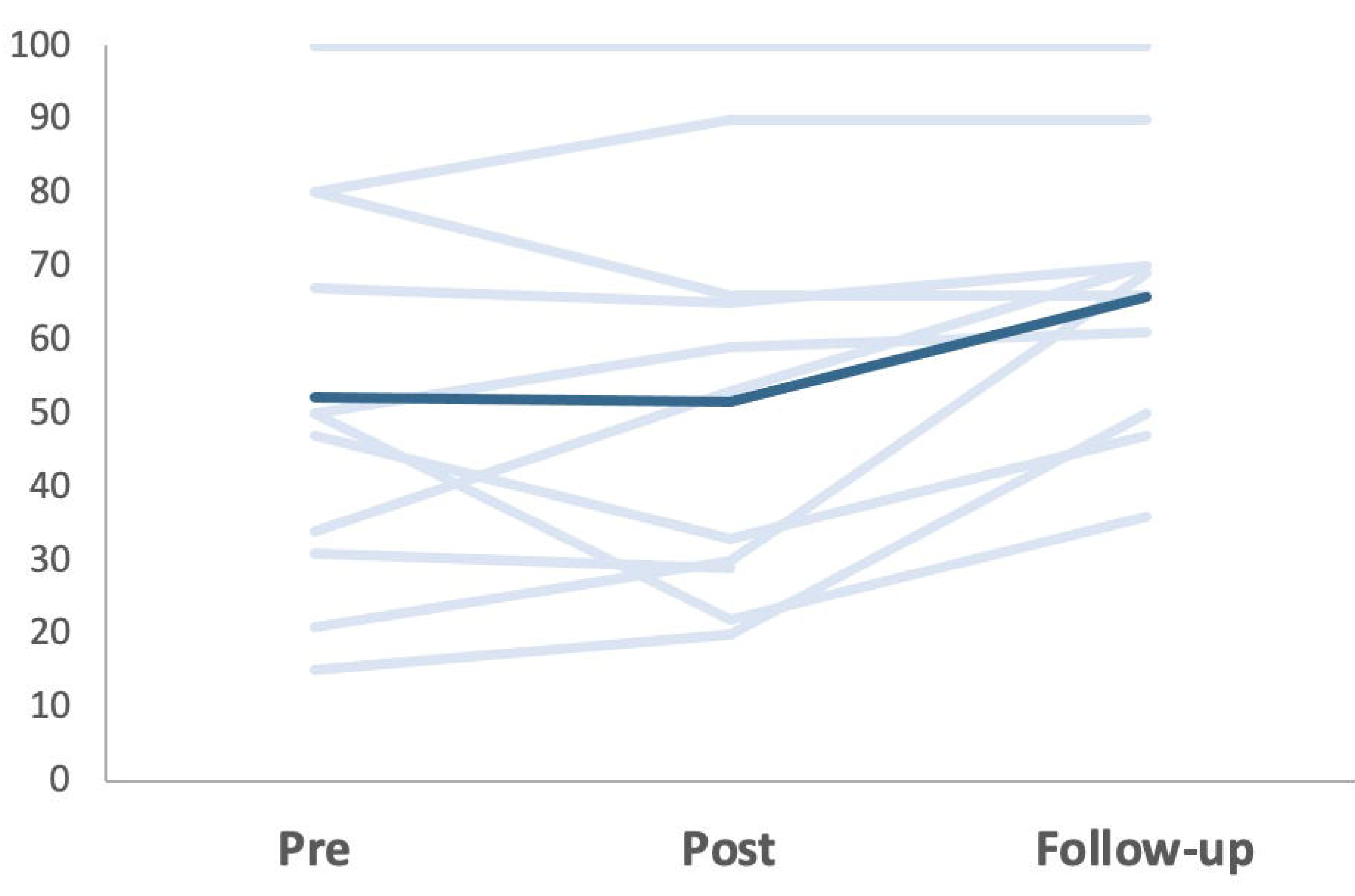

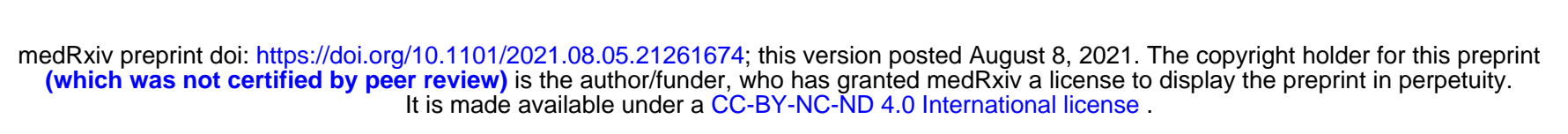

D Hospital Anxiety and Depression Scale (depression)

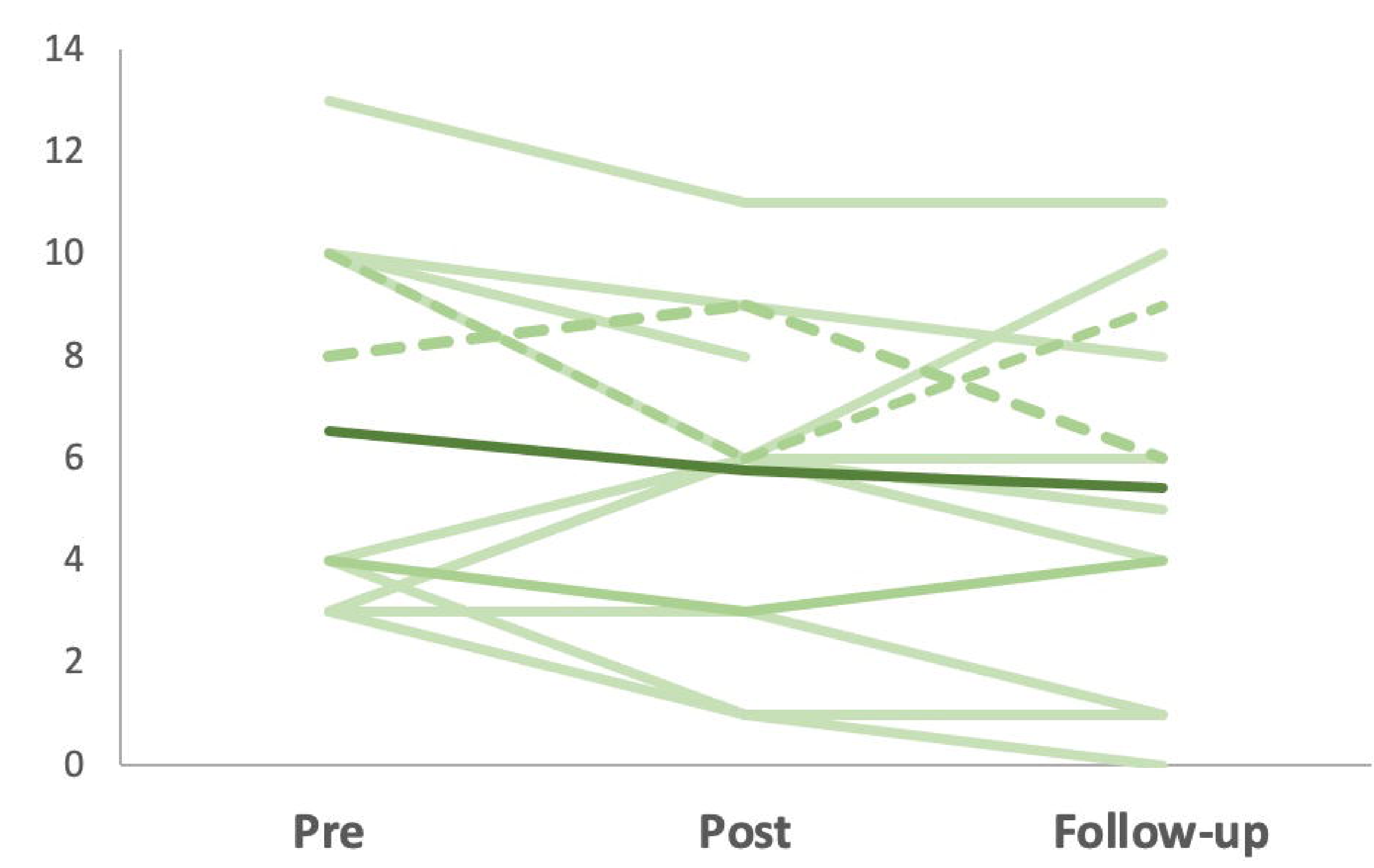

450
400
350
300
250
200
150

E

Hospital Anxiety and Depression Scale (anxiety)

$\mathbf{F}$

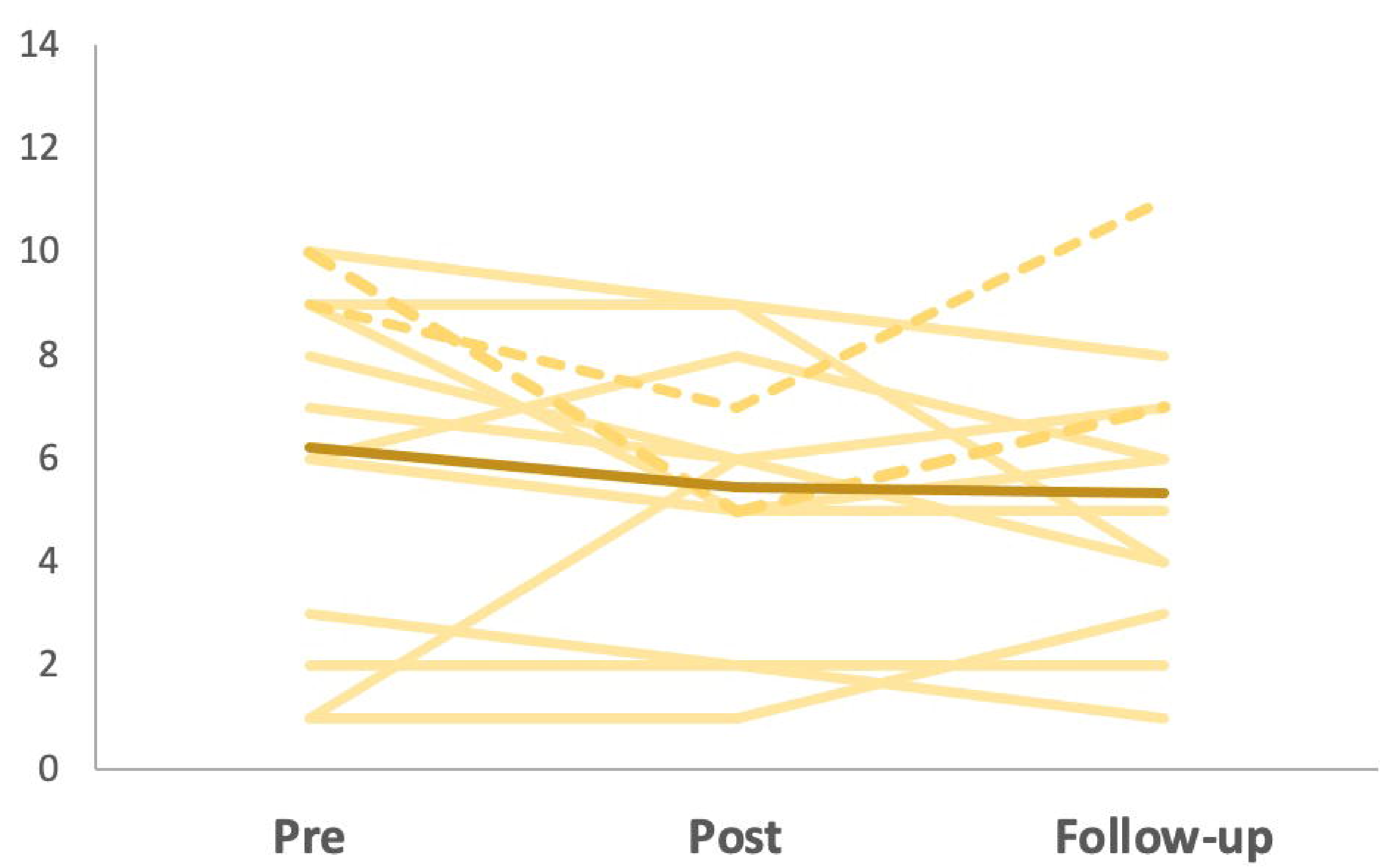

C

Single-item sleep quality

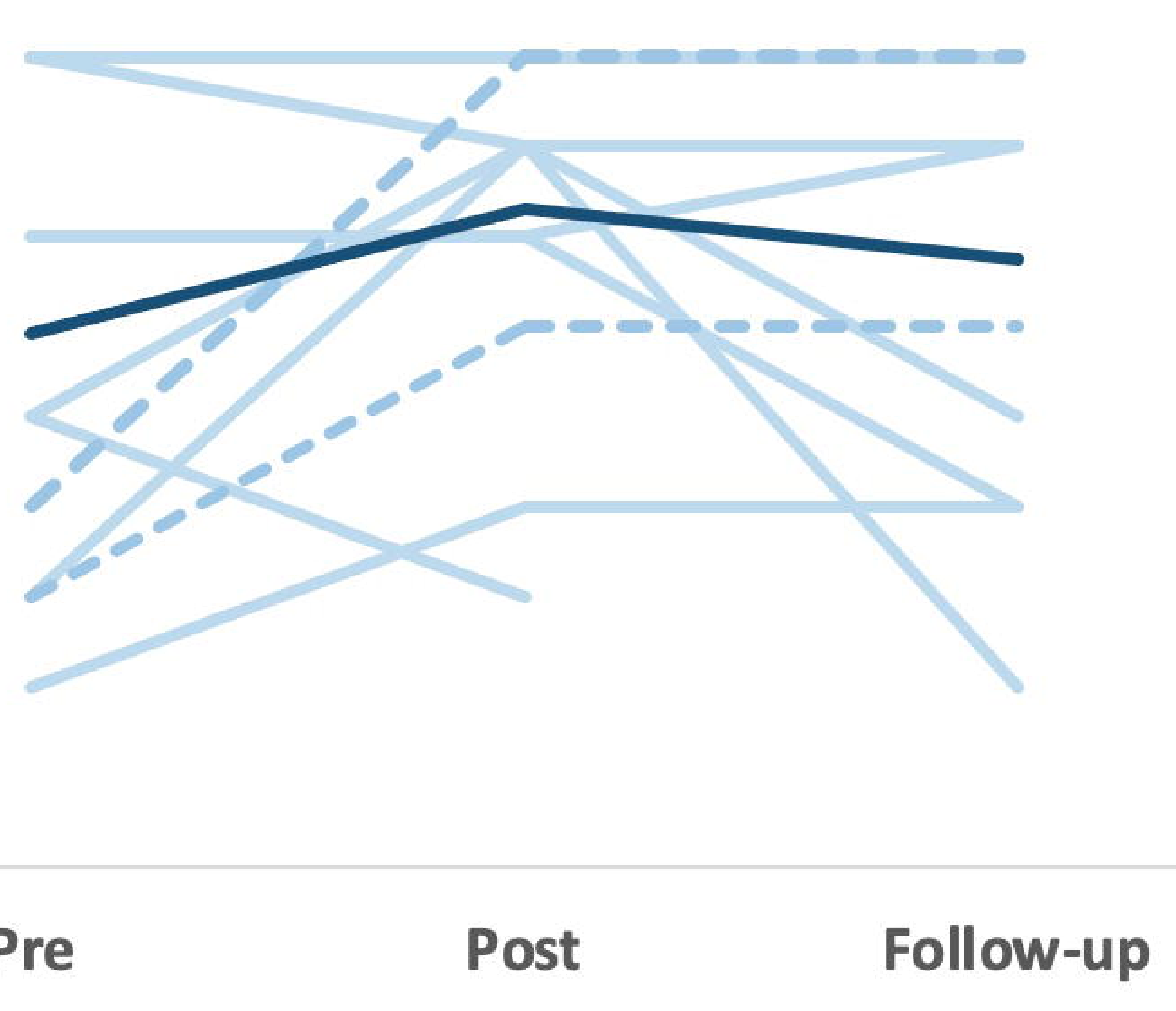

NIH Perceived stress
45

40

35

30

25

20

15

10

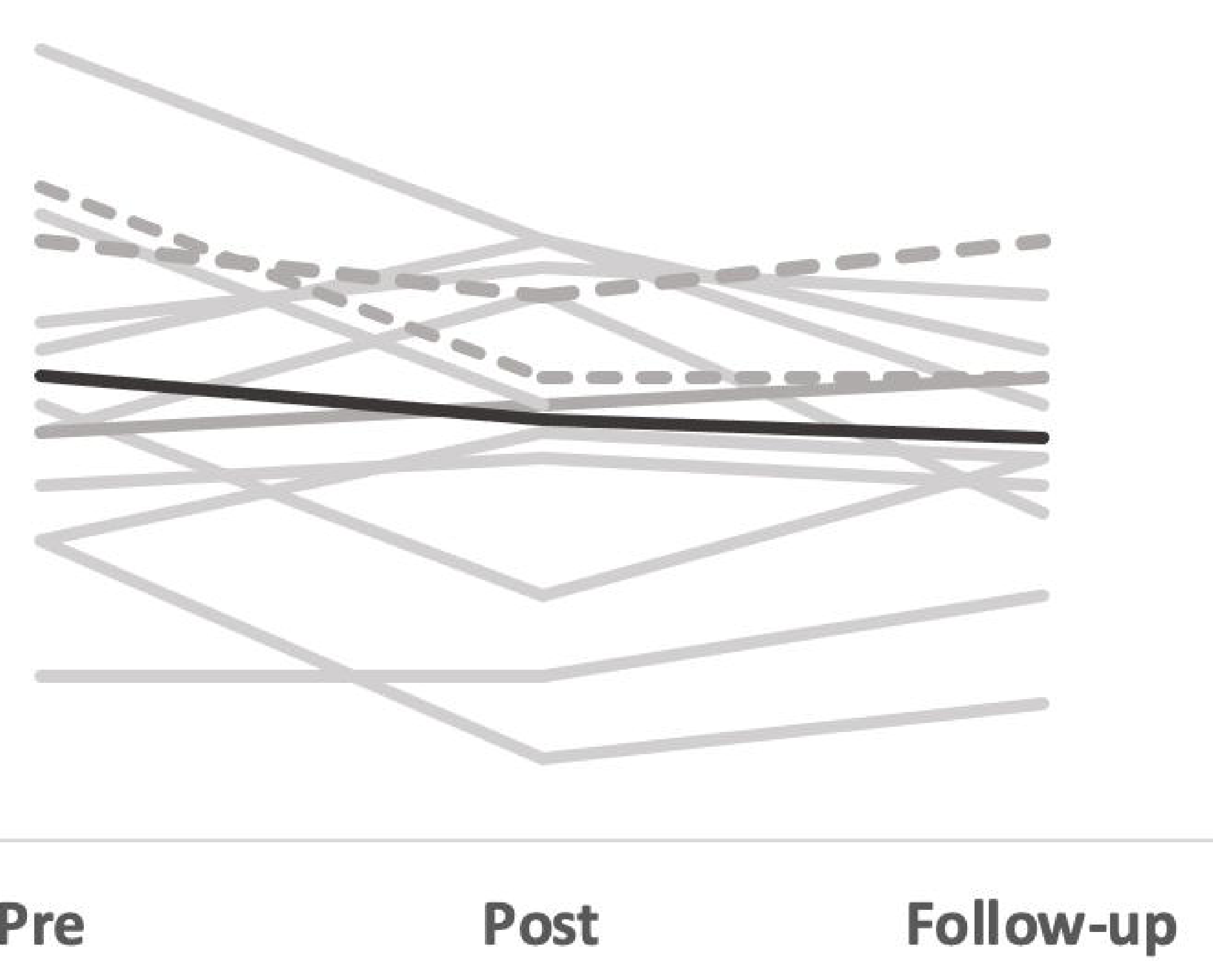

